\title{
Analisis Pengaruh Persepsi Kemudahan Penggunaan dan Persepsi Manfaat terhadap Minat Beli dengan Kepercayaan Sebagai Variabel Intervening (Studi pada Pengunjung Toko Online berrybenka.com di Kalangan Mahasiswa Universitas Diponegoro)
}

\author{
Rr. Selli Nisrina Faradila*, Harry Soesanto ${ }^{1}$ \\ Email : sellinisrina@gmail.com \\ Jurusan Manajemen Fakultas Ekonomika dan Bisnis Universitas Diponegoro \\ Jl. Prof. Soedharto SH Tembalang, Semarang 50239, Phone: +622476486851
}

\begin{abstract}
This study aimed to analyze the influence of perceived ease of use and perceived usefulness on purchase intention using trust as mediator study case on online store berrybenka.com. This study used two independent variables that are perceived ease of use and perceived usefulness, purchase intention variable as a dependent variable and trust variable as an intervening variable. Simple random sampling method is used for this research. Sample were collected from 150 respondents who ever had used berrybenka.com website. Multiple regression analysis is used for this study. The results showed that perceived ease of use have positive and significant effect on trust, perceived usefulness have positive and significant effect on trust and perceived ease of use, perceived usefulness, and trust have positive and significant effect on purchase intention.
\end{abstract}

Keywords : Perceived Ease of Use, Perceived Usefulness, Trust, Purchase Intention

\section{PENDAHULUAN}

Menurut Kotler dan Keller (2009) produk fashion termasuk dalam kategori durable goods yaitu produk yang dikonsumsi dengan jarak frekuensi yang panjang dan cukup lama dengan umur ekonomis dengan pemakaian normal adalah lebih dari satu tahun. Produk fashion meliputi pakaian, tas, sepatu, aksesoris, dan sebagainya. Kebutuhan akan produk jenis ini sudah menjadi kebutuhan pokok, khususnya bagi kaum wanita. Untuk memenuhi kebutuhan tersebut, penting bagi perusahaan untuk memperhatikan aspek kemudahan dan kecepatan bagi calon konsumen untuk mencari informasi mengenai produk yang dijual. Internet sebagai media bertransaksi secara online telah memberikan kemudahan dan kecepatan dalam melakukan transaksi bisnis di mana saja dan kapan saja. Aktivitas perdagangan online dapat juga disebut sebagai e-commerce.

Menurut O'Keefe et al. (2000) terdapat dua hal yang membedakan $e$ commerce dengan aktivitas perdagangan konvensional. Pertama, dalam $e$ commerce konsumen harus berinteraksi dengan teknologi untuk membeli suatu produk atau jasa yang mereka butuhkan. Toko offline diganti dengan lingkungan belanja elektronik atau bisa disebut sebagai sistem informasi (SI). Kedua, dibutuhkan tingkat kepercayaan yang lebih tinggi dalam berbelanja online dibandingkan dengan belanja offline. Tan dan Thoen (2001) mengatakan bahwa kepercayaan dalam berbelanja online merupakan faktor yang sangat penting dikarenakan rasa percaya dapat mengurangi ketidakpastian yang 
dirasakan konsumen ketika pemilik toko, kualitas produk, dan kinerja sebuah sistem tidak diketahui. Kondisi seperti itu dapat ditemukan dalam lingkungan berbelanja online dikarenakan pengetahuan konsumen atas produk terbatas hanya dari informasi yang tersedia tanpa bisa menyentuh fisik produk tersebut. Oleh karena itu, terdapat beberapa hal yang harus diperhatikan saat membentuk sebuah website toko online agar dapat memperoleh kepercayaan dari pengguna website.

Bart et al. (2005) mengemukakan bahwa elemen dalam website sebuah toko online merupakan hal krusial dalam membangun kepercayaan konsumen dan perlu dirancang dengan baik sebagai bagian dari strategi pemasaran online. Masing-masing website yang ada saat ini memiliki karakteristik yang berbedabeda dari segi privasi, navigasi, atau keamanan. Perusahaan perlu memperhatikan kemudahan penggunaan dan manfaat yang berkaitan dengan elemen-elemen tersebut.

Dari penjelasan di atas, dapat disimpulkan bahwa kemudahan dalam penggunaan dan manfaat yang dirasakan saat seseorang membuka website tertentu dapat mempengaruhi kepercayaannya terhadap toko online tersebut. Kepercayaan yang dapat diperoleh dapat berdampak pada kemajuan sebuah toko online.

Penelitian ini menganalisis pengaruh persepsi kemudahan penggunaan dan persepsi manfaat terhadap minat beli dengan kepercayaan sebagai variabel intervening.

\section{KERANGKA PEMIKIRAN TEORITIS DAN PERUMUSAN HIPOTESIS \\ Gambar 1 \\ Kerangka Pemikiran Teori}

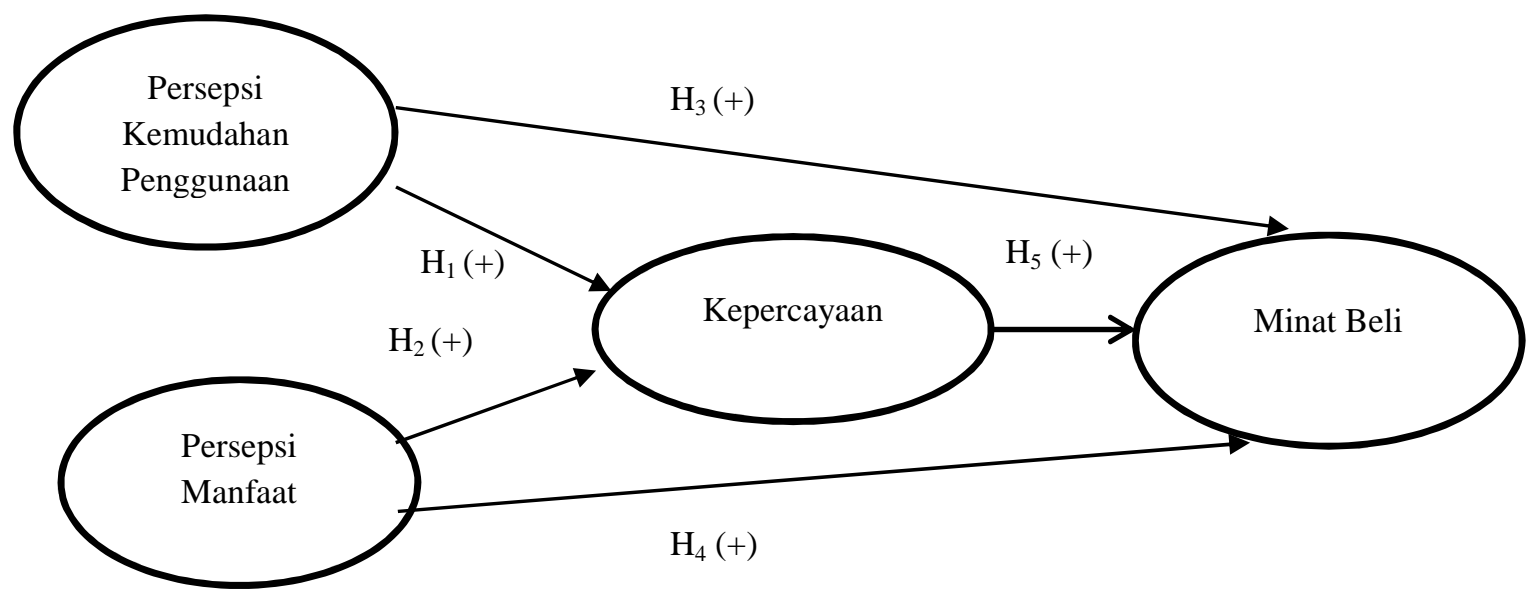

Sumber: Geffen et al. (2003), Ghazizadeh et al. (2012), Kim et al. (2008), Ramayah dan Igantius (2005), Haryosasongko (2015)

\section{Pengaruh Persepsi Kemudahan Penggunaan terhadap Kepercayaan}

Penelitian yang dilakukan oleh Geffen et al. (2003) menganalisis pengaruh persepsi kemudahan penggunaan terhadap kepercayaan. Hasil penelitian tersebut menunjukan persepsi kemudahan penggunaan memiliki pengaruh yang positif dan signifikan terhadap kepercayaan. Hal ini berarti bahwa semakin tingginya persepsi kemudahan penggunaan yang dirasakan konsumen, maka akan semakin tinggi juga tingkat kepercayaan.

Hoffman dan Novak (1996) mengatakan bahwa persepsi kemudahan penggunaan terhadap suatu website berkaitan dengan dua elemen, yaitu navigasi dan presentasi. Keduanya merupakan elemen-elemen pada website berupa tampilan, tata letak, animasi, dan gambar. 
Hasil yang sama dapat ditemukan pada salah satu faktor yang membentuk kepercayaan terhadap toko online dalam penelitian yang dilakukan Cheskin Research seperti yang dikuti oleh Yoon (2002), yaitu faktor presentasi di antara faktor-faktor lain yang ditemukan seperti terjaminnya keamanan, merek, pencarian, dan teknologi.

Dari penjelasan di atas dapat disimpulkan bahwa persepsi kemudahan penggunaan berkaitan dengan navigasi, presentasi, kenyamanan, dan kemudahan yang dapat diberikan suatu website. Jika sebuah website dapat memenuhinya, maka kepercayaan dapat diperoleh. Bart et al. (2005) mengatakan sebuah website dikatakan dapat dipercaya jika pengguna website hanya harus melakukan klik seminimum mungkin untuk mendapatnya apa yang mereka butuhkan dari website tersebut.

$H_{1}$ :Persepsi kemudahan penggunaan berpengaruh positif terhadap kepercayaan.

Pengaruh Persepsi Manfaat terhadap Kepercayaan

Koufaris dan Hampton-Sosa (2004) mengatakan bahwa tingkat kemanfaatan sebuah website memiliki kaitan dengan meningkatnya performansi dan produktivitas berbelanja saat menggunakan website tersebut. Performansi berkaitan dengan kecepatan akses saat menggunakan website, sedangkan produktivitas berkaitan dengan manfaat yang dirasakan saat menemukan produkproduk lain dengan mudah.

Penelitian yang dilakukan oleh Ghazizadeh et al. (2012) menunjukkan pengaruh persepsi manfaat yang positif dan signifikan terhadap kepercayaan. Hal tersebut berarti bahwa semakin tinggi persepsi akan manfaat yang dirasakan, maka semakin tinggi juga tingkat kepercayaan.

$\mathrm{H}_{2}$ :Persepsi manfaat berpengaruh positif terhadap kepercayaan.

Pengaruh Persepsi Kemudahan Penggunaan Terhadap Minat Beli website menjadi pertimbangan konsumen sebelum melakukan belanja online. Meskipun belanja online memiliki banyak manfaat, namun kerumitan dalam berinteraksi dengan medianya dalam hal ini adalah situs jual beli online, bisa menjadi sesuatu yang membingungkan untuk pengguna. Haubl dan Trifts (dalam Heijden et al., 2003) mengatakan bahwa teknologi yang digunakan situs belanja online yaitu internet, berpotensi untuk mengurangi biaya pencarian dan evaluasi alternatifalternatif dan dapat meningkatkan ketertarikan pengguna website terhadap produk-produk yang dijual. Oleh karena itu, kemudahan penggunaan suatu website perlu diperhatikan. Kemudahan penggunaan suatu situs belanja online berhubungan dengan mudah atau tidaknya situs digunakan oleh calon pembeli. Jika komponen-komponen pada website rumit dan sulit dipelajari, pengguna website cenderung mengurungkan niatnya dalam berbelanja online.

Kerumitan penggunaan situs belanja online menurut Ramayah dan Ignatius (2005) dipengaruhi beberapa faktor seperti lamanya waktu untuk membuka situs tersebut, buruknya rancangan tampilan situs, dan peletakan menu yang tidak rapi. Jika penggunaan situs ternyata lebih rumit dibandingkan manfaat yang diperoleh, maka pengguna berpotensi akan lebih memilih berbelanja secara konvensional. Namun jika situs lebih mudah digunakan dan memberikan manfaat, calon pembeli akan menggunakan situs tersebut untuk berbelanja online.

Faktor-faktor tersebut dapat menjadi hambatan saat seseorang menggunakan suatu website yang berakibat mengurangi persepsi pengguna tentang kemudahan penggunaan website tersebut, hal ini memungkinkan pengguna untuk memunculkan sikap negatif terhadap situs tersebut. Sikap negatif ini akan berpengaruh kepada minat beli pengguna. Succi dan Walter dalam Nurrahmanto (2015) mengatakan bahwa sebuah sistem yang dinilai mudah 
digunakan secara otomatis akan mempengaruhi perilaku seseorang untuk menggunakannya. Situs jual beli online dapat dikatakan baik jika situs tersebut menyediakan petunjuk jelas alur bertransaksi, mulai dari pemesanan, pembayaran, pengisian formulir, hingga produk sampai di tangan pembeli. Situs jual beli online tidak hanya harus menarik secara teknis, tetapi juga harus mudah dalam penggunaannya agar memberikan dorongan terhadap penggunanya untuk melakukan berbelanja online disana.

$\mathrm{H}_{3}$ : Persepsi kemudahan penggunaan berpengaruh positif terhadap minat beli.

\section{Pengaruh Persepsi Manfaat Terhadap Minat Beli}

Menurut Kim et al. (2007) dalam e-commerce persepsi manfaat merupakan keyakinan seseorang tentang sejauh mana ia akan menjadi lebih baik dari penggunaan situs belanja online tertentu. Seperti penggunaan suatu situs e-commerce memungkinkan seseorang untuk mempersingkat waktu berbelanja.

Dalam menggunakan suatu situs belanja online, seseorang menginginkan untuk memperoleh manfaat. Seperti efisiensi waktu karena akses website yang cepat, memudahkan pembelian produk, dan kegunaan untuk melakukan suatu aktivitas. Dalam penelitian Lee dan Wan (2010) yang menggunakan studi kasus pada e-ticket maskapai penerbangan, manfaat dari menggunakan website penjualan tiket online adalah berupa bergunanya website tersebut untuk melakukan perjalanan udara. Jadi persepsi manfaat yang dirasakan terhadap suatu website dapat ditingkatkan ketika website tersebut mampu memberikan manfaat atau memudahkan berlangsungnya suatu aktivitas dari penggunanya.

Untuk situs e-commerce, persepsi manfaat yang dirasakan berarti dapat bergunanya situs tersebut dalam memudahkan berlangsungnya proses belanja online. Jika situs e-commerce dilengkapi dengan akses yang cepat, kemudahan pencarian produk, dan sesuai dengan kebutuhan pengguna maka hal tersebut dapat memunculkan sikap positif dari pengguna terhadap situs tersebut. Penelitian dari Haryosasongko (2015) menunjukkan persepsi manfaat berpengaruh positif terhadap minat beli.

$\mathrm{H}_{4}$ :Persepsi manfaat berpengaruh positif terhadap minat beli.

\section{Pengaruh Kepercayaan terhadap Minat Beli}

Cheskin Research (1999)

menunjukkan bahwa terdapat tiga tahap yang dilalui sebelum seseorang dapat memperoleh kepercayaan terhadap suatu website. Tahap pertama disebut sebagai tahap chaos atau kekacauan, dikarenakan pengunjung website masuk ke lingkungan baru yang membuatnya khawatir akan keamanan informasi, ketidakpercayaannya terhadap teknologi internet, dan hasil dari pencarian yang tidak bisa diprediksi. Oleh karena itu pada tahap chaos, pengunjung website akan berusaha melakukan kontrol atas informasi pribadi apa saja yang bisa mereka cantumkan secara online. Tahap kedua disebut trust confirmation atau konfirmasi kepercayaan, dikarenakan pada tahap ini pengunjung website akan mencari pembenaran bahwa website tersebut dapat dipercaya mampu menjaga kerahasiaan informasi mereka. Tahap ketiga disebut maintaining trust atau menjaga kepercayaan, tahap di saat pengunjung website akhirnya dapat memperoleh kepercayaan atas website tersebut. Pada tahap ini pengunjung website telah meningkatkan perhatiannya terhadap merek atau produk yang dijual, yang dapat menjadi stimulus untuk membeli produk-produk tersebut.

Penelitian yang dilakukan oleh Yoon (2002) menunjukkan bahwa kepercayaan berpengaruh positif terhadap minat beli. Hal ini berarti bahwa semakin tinggi tingkat kepercayaan, maka akan semakin tinggi juga minat beli. Penelitian tersebut juga menunjukkan bahwa toko yang hanya beroperasi secara online seperti yang digunakan pada penelitian tersebut, 
Metaland dan Zigtown, terbukti lebih membutuhkan tingkat kepercayaan lebih tinggi dibandingkan dengan toko yang beroperasi dengan dua media yaitu online dan offline seperti Shinsegae dan Lotte. Oleh karena itu toko yang hanya beroperasi secara online membutuhkan usaha yang lebih besar untuk memperoleh kepercayaan dibandingkan dengan toko yang juga beroperasi secara offline. Penelitian selanjutnya oleh Kim et al. (2008) juga menunjukkan bahwa kepercayaan berpengaruh positif terhadap minat beli.

$H_{5}$ : Kepercayaan berpengaruh positif terhadap minat beli.

$\mathrm{H}_{1}$ : Persepsi kemudahan penggunaan berpengaruh positif terhadap kepercayaan.

$\mathrm{H}_{2}$ : Persepsi manfaat berpengaruh positif terhadap kepercayaan.

$\mathrm{H}_{3}$ : Persepsi kemudahan penggunaan berpengaruh positif terhadap minat beli.

$\mathrm{H}_{4}$ : Persepsi manfaat berpengaruh positif terhadap minat beli.

$\mathrm{H}_{5}$ : Kepercayaan berpengaruh positif terhadap minat beli.

\section{METODE PENELITIAN Variabel Penelitian}

Davis (1989) mendefinisikan persepsi kemudahan penggunaan atau perceived ease of use sebagai tingkat seberapa besar seseorang dapat percaya bahwa dalam menggunakan suatu sistem tidak akan menyulitkannya. Penelitian ini menggunakan alat ukur persepsi kemudahan penggunaan dengan 3 indikator yaitu: Kemudahan untuk mempelajari penggunaan website $\left(\mathrm{X}_{1.1}\right)$, Kemudahan untuk menggunakan website sesuai dengan kebutuhan $\left(\mathrm{X}_{1.2}\right)$, dan Kemudahan menggunakan website dengan terampil dan tanpa kesulitan $\left(\mathrm{X}_{1.4}\right)$.

Davis (1989) mendefinisikan
persepsi manfaat atau perceived
usefulness sebagai persepsi yang
dirasakan mengenai seberapa besar
tingkat kemanfaatan yang dapat
diperoleh. Dalam konteks website

sebuah toko online, persepsi manfaat dapat didefinisikan sebagai persepsi yang dirasakan pengguna website atas utilitas dari website tersebut. Persepsi manfaat diukur dengan menggunakan 3 indikator yaitu: Penggunaan website dapat meningkatkan performansi berbelanja $\left(\mathrm{X}_{2 \cdot 1}\right)$, Penggunaan website dapat meningkatkan produktivitas berbelanja $\left(\mathrm{X}_{2.2}\right)$, dan Penggunaan website dapat meningkatkan efektivitas berbelanja $\left(\mathrm{X}_{2 \cdot 3}\right)$.

Definisi kepercayaan menurut Rousseau et al. (1998) merupakah kondisi psikologis seseorang yang bersedia menerima kerentanan suatu situasi berpegang pada harapan-harapan yang positif mengenai sikap atau niat orang lain. Hal itu berarti kepercayaan dapat ditimbulkan pada diri seseorang karena adanya faktor-faktor yang memberi harapan positif meskipun lingkungan di sekitarnya memberi ketidakpastian. Kepercayaan diukur dengan menggunakan 3 indikator yaitu: Website dapat dipercaya $\left(\mathrm{Y}_{1.1}\right)$, Website dikenal sebagai situs $e$ commerce yang dapat memenuhi janjinya $\left(\mathrm{Y}_{1 \cdot 2}\right)$, dan Tidak ada alasan untuk khawatir saat menggunakan website $\left(\mathrm{Y}_{1 \cdot 3}\right)$. Menurut Keller (1998) minat beli merupakan seberapa besar tingkat kemungkinan kosumen membeli suatu merek atau berpindah dari satu merek ke merek lainnya. Minat beli diukur dengan menggunakan 3 indikator yaitu: Minat Preferensial $\left(\mathrm{Y}_{2 \cdot 1}\right)$, Minat Transaksional $\left(\mathrm{Y}_{2.2}\right)$, dan Minat Eksploratif $\left(\mathrm{Y}_{2 \cdot 3}\right)$.

\section{Penentuan Sampel}

Populasi pada penelitian ini adalah mahasiswa Fakultas Ekonomika dan Bisnis dan mahasiswa Fakultas Hukum Universitas Diponegoro yang pernah membuka situs berrybenka.com. Pemilihan objek penelitian ini berdasarkan pada pengamatan terhadap penampilan mahasiswa Fakultas Ekonomika dan Bisnis serta Fakultas Hukum Universitas Diponegoro yang terus mengikuti tren fashion terbaru. 
Dalam pengambilan sampel peneliti menggunakan teknik pengambilan sampel purposive sampling. Pada teknik sampel diambil dari satu kelompok sasaran tertentu yang mampu memberikan informasi dengan kriteria yang ditentukan oleh peneliti (Ferdinand, 2006). Maka sampel yang digunakan pada penelitian ini adalah 150 mahasiswa Fakultas Ekonomika dan Bisnis serta Fakultas Hukum Universitas Diponegoro yang pernah membuka situs berrybenka.com.

Hasil uji coba menunjukkan bahwa kuesioner valid dan reliable. Jenis data yang digunakan dalam penelitian ini adalah data kuantitatif. Lokasi penelitian pada toko online berrybenka.com.

Metode Analisis
Alat analisis yang digunakan pada penelitian ini adalah melalui program SPSS 23.0 dengan regresi linier berganda dengan 2 alat analisis yaitu deskriptif kuantitatif dan deskriptif kualitatif dimana untuk deskriptif kualitatif terdapat angka indeks. Untuk mendapatkan gambaran mengenai derajat persepsi responden atas variabel yang akan diteliti maka dikembangkan sebuah angka indeks. (Ferdinand, 2006). Serta uraian dari pertanyaan terbuka untuk mengetahui pengaruh persepsi kemudahan penggunaan dan persepsi manfaat terhadap kepercayaan dan dampaknya pada minat beli.

HASIL PENELITIAN DAN

PEMBAHASAN

Deskripsi Sampel Penelitian

Deskripsi sampel pada penelitian ini adalah sebagai berikut:

Tabel 1.1

Deskripsi Sampel Penelitian

\begin{tabular}{llll}
\hline No & \multicolumn{1}{c}{$\begin{array}{c}\text { Karakteristik } \\
\text { Demografi }\end{array}$} & \multicolumn{1}{c}{ Kategori } & \multicolumn{1}{c}{$\begin{array}{c}\text { Frekuensi } \\
\text { (orang) }\end{array}$} \\
\hline 1. & Jenis Kelamin & a. Pria & 45 \\
& & b. Wanita & 105 \\
2. & \multirow{2}{*}{ Usia } & a. $<19$ tahun & 30 \\
\multirow{2}{*}{ 5. Penghasilan perbulan } & b. 19 tahun - 29 tahun & 120 \\
& & a. Rp300.000 - Rp 500.000 & 20 \\
& & b.> Rp 500.000 - Rp 1.000.000 & 39 \\
& & c. > Rp 1.000.000 - Rp 1.500.000 & 41 \\
& & d. > Rp 1.500.000 - Rp 2.000.000 & 30 \\
& & e. > Rp 2.000.000 & 20 \\
\hline
\end{tabular}

\section{Pembahasan Hasil Penelitian}

Proses analisis data yang digunakan dalam penelitian ini menggunakan SPSS. Pada tahap awal, data harus diuji terlebih dahulu melalui uji validitas dan reliabilitas. Selanjutnya uji asumsi klasik, dan uji goodness of fit.

\section{Uji Reliabilitas dan Validitas}

Berdasarkan analisis yang telah dilakukan, dapat diketahui bahwa model kuesioner dikatakan valid dan reliabel. Suatu model dikatakan valid apabila nilai $r_{\text {hitung }}>r_{\text {tabel }}$ dan suatu model dikatakan reliabel apabila nilai cronbach alpha > 0,6 (Ghozali, 2006). Nilai cronbach alpha untuk variabel persepsi kemudahan penggunaan adalah 0,814 , persepsi manfaat 0,748 , kepercayaan 0,811, dan minat beli 0,779 .

\section{Uji Asumsi Klasik}

Pada uji asumsi klasik, terdapat tiga metode yang harus diuji, yaitu uji normalitas, uji multikolinearitas, dan uji heteroskedastisitas. Pada uji normalitas, diuji menggunakan probability plots untuk melihat apakah berdistribusi normal atau tidak (Ghozali, 2006). Berdasarkan data yang didapat, diketahui bahwa titik-titik menyebar mengikuti garis diagonal, hal ini menunjukan bahwa model yang diuji berdistribusi normal.

Selanjutnya untuk uji multikolinearitas dapat dilihat melalui nilai tolerance dan VIF. Suatu model 
dikatakan tidak terjadi multikolinearitas apabila nilai tolerance $\geq 0,1$ dan VIF $\leq$ 10 (Ghozali, 2006). Dari hasil analisis data diketahui bahwa tidak terjadi multikolinearitas, dikarenakan semua nilai VIF diatas 1 dan kurang dari 10 dengan nilai tolerance $\geq 0,1$.

Uji Heteroskedastisitas dilakukan untuk menguji apakah dalam model regresi terjadi ketidaksamaan varians dari residul satu pengamatan ke pengamatan lain (Ghozali, 2006). Model regresi yang baik adalah tidak terjadi heteroskesdatisitas atau homoskesdatisitas. Dapat dilihat melalalui grafik plot ZPRED dengan SRESID, apabila titik-titik menyebar kesegala arah tanpa membuat pola tertentu, maka tidak terjadi heteroskesdastisitas. Berdasarkan hasil analisis data dapat diketahui bahwa titiktitik menyebar kesegala arah tanpa membuat pola tertentu sehingga dapat disimpulkan bahwa tidak terjadi heteroskesdastisitas atau homoskesdatisitas.

\section{Uji Goodness Of Fit}

Dari hasil analisis SPSS, diketahui bahwa nilai Adjusted $\mathrm{R}$ Square pada uji koefisien determinasi struktur 1 sebesar 0,538. Artinya persepsi kemudahan penggunaan dan persepsi manfaat dapat menjelaskan kepercayaan sebesar 53,8\% dan sisanya dijelaskan oleh variabel lain. Selain itu dapat diketahui pula bahwa pada uji koefisien determinasi struktur 2 menghasilkan nilai Adjusted R Square sebesar 0,579, artinya persepsi kemudahan penggunaan, persepsi manfaat, dan kepercayaan dapat menjelaskan minat beli sebesar $57,9 \%$ dan sisanya dijelaskan oleh variabel lain.

Uji t dilakukan untuk menunjukan seberapa jauh pengaruh variabel independent dalam menjelaskan variabel dependen dengan kriteria nilai $t_{\text {hitung }} \geq$ $t_{\text {tabel }}$ atau nilai sig $\leq 0,05$. Dalam penelitian ini, uji t dilakukan dua kali. Hasil yang pertama dan kedua menunjukan bahwa nilai $t_{\text {hitung }}$ variabel persepsi kemudahan penggunaan, persepsi manfaat, kepercayaan, dan minat beli telah lebih dari $\mathrm{t}_{\text {tabel }}$ dengan semua nilai sig $\leq 0,05$.

Uji F dilakukan untuk menunjukan apakah semua variabel independen yang dimasukan dalam model penelitian memiliki pengaruh secara bersama-sama terhadap variabel dependen. Pada penelitian ini dilakukan uji F sebanyak dua kali. Pada hasil uji F pertama, mendapatkan hasil $F_{\text {hitung }}$ sebesar 87,751 dengan tingkat signifikan 0,000 . Lalu pada hasil yang kedua, mendapatkan hasil $\mathrm{F}_{\text {hitung }} 69,193$ dengan tingkat signifikan 0,000. Dari hasil yang didapat, maka dapat disimpulkan bahwa persepsi kemudahan penggunaan dan persepsi manfaat dapat digunakan untuk memperediksi kepercayaan dan persepsi kemudahan penggunaan, persepsi manfaat, dan kepercayaan dapat memprediksi minat beli.

Dari sini dapat disimpulkan bahwa variabel persepsi kemudahan penggunaan dan persepsi manfaat berpengaruh positif dan signifikan terhadap kepercayaan dan variabel persepsi kemudahan penggunaan, persepsi manfaat, dan kepercayaan berpengaruh secara positif dan signifikan terhadap minat beli dengan persamaan regresi yaitu:

$$
\begin{gathered}
\mathrm{Y}_{1}=0,266 \mathrm{X}_{1}+0,506 \mathrm{X}_{2} \\
\mathrm{Y}_{2}=0,289 \mathrm{X}_{1}+0,234 \mathrm{X}_{2}+ \\
0,324 \mathrm{Y}_{1}
\end{gathered}
$$

$$
\text { Dimana: } \begin{aligned}
\mathrm{Y}_{2} & =\text { Minat beli } \\
\mathrm{Y}_{1} & =\text { Kepercayaan } \\
\mathrm{X}_{1} & =\text { Persepsi Kemudahan } \\
& \quad \text { Penggunaan } \\
\mathrm{X}_{2} & =\text { Persepsi Manfaat }
\end{aligned}
$$


Tabel 1.2

Uji t Model I

Coefficients $^{\mathrm{a}}$

\begin{tabular}{|c|c|c|c|c|c|c|c|c|}
\hline \multirow[b]{2}{*}{ Model } & & \multicolumn{2}{|c|}{$\begin{array}{l}\text { Unstandardized } \\
\text { Coefficients }\end{array}$} & \multirow{2}{*}{$\begin{array}{c}\begin{array}{c}\text { Standardized } \\
\text { Coefficients }\end{array} \\
\text { Beta } \\
\end{array}$} & \multirow[b]{2}{*}{$\mathbf{T}$} & \multirow[b]{2}{*}{ Sig. } & \multicolumn{2}{|c|}{$\begin{array}{c}\text { Collinearity } \\
\text { Statistics }\end{array}$} \\
\hline & & B & $\begin{array}{c}\text { Std. } \\
\text { Error }\end{array}$ & & & & Tolerance & VIF \\
\hline \multirow[t]{3}{*}{1} & (Constant) & 3,471 & 1,351 & & 2,570 &, 011 & & \\
\hline & $\begin{array}{l}\text { Persepsi } \\
\text { Kemudahan } \\
\text { Penggunaan }\end{array}$ & ,253 & ,089 & ,266 & 2,832 & ,005 &, 351 & 2,850 \\
\hline & $\begin{array}{l}\text { Persepsi } \\
\text { Manfaat }\end{array}$ & ,573 & , 106 & ,506 & 5,384 & , 000 & ,351 & 2,850 \\
\hline
\end{tabular}

a. Dependent Variable: Kepercayaan

Tabel 1.3

Uji t Model II

Coefficients $^{\mathrm{a}}$

\begin{tabular}{|c|c|c|c|c|c|c|c|c|}
\hline \multirow[b]{2}{*}{ Model } & & \multicolumn{2}{|c|}{$\begin{array}{c}\text { Unstandardized } \\
\text { Coefficients }\end{array}$} & \multirow{2}{*}{$\begin{array}{c}\begin{array}{c}\text { Standardized } \\
\text { Coefficients }\end{array} \\
\text { Beta } \\
\end{array}$} & \multirow[b]{2}{*}{$\mathbf{T}$} & \multirow[b]{2}{*}{ Sig. } & \multicolumn{2}{|c|}{$\begin{array}{c}\text { Collinearity } \\
\text { Statistics }\end{array}$} \\
\hline & & B & $\begin{array}{l}\text { Std. } \\
\text { Error }\end{array}$ & & & & Tolerance & VIF \\
\hline 1 & (Constant) & 3,705 & 1,239 & & 2,992 &, 003 & & \\
\hline & $\begin{array}{l}\text { Persepsi } \\
\text { Kemudahan } \\
\text { Penggunaan }\end{array}$ & ,258 & ,082 & ,289 & 3,132 & ,002 &, 333 & 3,005 \\
\hline & Persepsi Manfaat & ,249 & ,104 & ,234 & 2,383 & ,018 & 293 & 3,412 \\
\hline & Kepercayaan & ,304 & ,074 & ,324 & 4,110 & ,000 & ,456 & 2,194 \\
\hline
\end{tabular}

a. Dependent Variable: Minat Beli

\section{Kesimpulan Hipotesis}

$\mathrm{H}_{1}$ : Persepsi kemudahan penggunaan berpengaruh positif terhadap kepercayaan.

Berdasarkan tabel 1.2 dapat dilihat bahwa nilai $t_{\text {hitung }}$ untuk persepsi kemudahan penggunaan sebesar 2,832 dengan tingkat signifikan 0,005 . Hal ini dapat disimpulkan bahwa persepsi kemudahan penggunaan berpengaruh secara positif dan signifikan terhadap kepercayaan dikarenakan nilai $t_{\text {hitung }} \geq$ $t_{\text {tabel }}$ dan sig $\leq 0,05$. Sehingga $\mathbf{H}_{\mathbf{1}}$ diterima.

$\mathrm{H}_{2}$ : Persepsi manfaat berpengaruh positif terhadap kepercayaan.

Berdasarkan tabel 1.2 dapat dilihat bahwa nilai $t_{\text {hitung }}$ untuk persepsi manfaat sebesar 5,384 dengan tingkat signifikan 0,000. Hal ini dapat disimpulkan bahwa persepsi manfaat berpengaruh secara positif dan signifikan terhadap kepercayaan dikarenakan nilai $t_{\text {hitung }} \geq t_{\text {tabel }}$ dan sig $\leq$ 0,05 . Sehingga $\mathbf{H}_{2}$ diterima.

$\mathrm{H}_{3}$ : Persepsi kemudahan penggunaan berpengaruh positif terhadap minat beli.

Berdasarkan tabel 1.3 dapat dilihat bahwa nilai $t_{\text {hitung }}$ untuk persepsi kemudahan penggunaan sebesar 3,132 dengan tingkat signifikan 0,002 . Hal ini dapat disimpulkan bahwa persepsi kemudahan penggunaan berpengaruh secara positif dan signifikan terhadap minat beli dikarenakan nilai $t_{\text {hitung }} \geq t_{\text {tabel }}$ dan sig $\leq 0,05$. Sehingga $\mathbf{H}_{3}$ diterima.

$\mathrm{H}_{4}$ : Persepsi manfaat berpengaruh positif terhadap minat beli.

Berdasarkan tabel 1.3 dapat dilihat bahwa nilai $t_{\text {hitung }}$ untuk persepsi manfaat sebesar 2,383 dengan tingkat 
signifikan 0,018. Hal ini dapat disimpulkan bahwa persepsi manfaat berpengaruh secara positif dan signifikan terhadap minat beli dikarenakan nilai $t_{\text {hitung }} \geq t_{\text {tabel }}$ dan sig $\leq$ 0,05. Sehingga $\mathbf{H}_{4}$ diterima.

\section{$\mathrm{H}_{5}$ : Kepercayaan berpengaruh positif} terhadap minat beli.

Berdasarkan tabel 1.3 dapat dilihat bahwa nilai $t_{\text {hitung }}$ untuk kepercayaan sebesar 4,110 dengan tingkat signifikan 0,000 . Hal ini dapat disimpulkan bahwa kepercayaan berpengaruh secara positif dan signifikan terhadap minat beli dikarenakan nilai $t_{\text {hitung }} \geq t_{\text {tabel }}$ dan sig $\leq$ 0,05. Sehingga $\mathbf{H}_{5}$ diterima.

\section{KESIMPULAN DAN \\ KETERBATASAN}

Dari hasil penelitian ini dengan judul "Analisis Pengaruh Persepsi Kemudahan Penggunaan dan Persepsi Manfaat Terhadap Minat Beli dengan Kepercayaan Sebagai Variabel Intervening (Studi Kasus Pada Pengunjung Toko Online berrybenka.com di Kalangan Mahasiswa Universitas Diponegoro). Maka dapat diambil kesimpulan sebagai berikut:

1. Hasil analisis menunjukkan adanya pengaruh positif dari variabel persepsi kemudahan penggunaan terhadap kepercayaan. Hasil pengujian kedua variabel tersebut menunjukkan bahwa koefisien regresi dari pengaruh persepsi kemudahan penggunaan terhadap kepercayaan adalah sebesar 0,266 dan bernilai positif. Tingkat signifikansinya sebesar 0,005 dimana nilai signifikansi tersebut $<\alpha(0,05)$, sehingga persepsi kemudahan penggunaan memiliki pengaruh yang positif dan signifikan terhadap kepercayaan.

2. Hasil analisis menunjukkan adanya pengaruh positif dan signifikan dari variabel persepsi manfaat terhadap kepercayaan. Hasil pengujian kedua variabel tersebut menunjukkan bahwa koefisien regresi dari pengaruh persepsi manfaat terhadap kepercayaan adalah sebesar 0,506 dan bernilai positif. Tingkat signifikansinya sebesar
0,000 dimana nilai signifikansi tersebut $<\alpha(0,05)$, sehingga persepsi manfaat memiliki pengaruh yang positif dan signifikan terhadap kepercayaan.

3. Hasil analisis menunjukkan adanya pengaruh positif dan signifikan dari variabel persepsi kemudahan penggunaan terhadap minat beli. Hasil pengujian kedua variabel tersebut menunjukkan bahwa koefisien regresi dari pengaruh persepsi kemudahan penggunaan terhadap minat beli adalah sebesar 0,289 dan bernilai positif. Tingkat signifikansinya sebesar 0,002 dimana nilai signifikansi tersebut $<\alpha$ $(0,05)$, sehingga persepsi kemudahan penggunaan memiliki pengaruh yang positif dan signifikan terhadap minat beli.

4. Hasil analisis menunjukkan adanya pengaruh positif dan signifikan dari variabel persepsi manfaat terhadap minat beli. Hasil pengujian kedua variabel tersebut menunjukkan bahwa koefisien regresi dari pengaruh persepsi manfaat terhadap minat beli adalah sebesar 0,234 dan bernilai positif. Tingkat signifikansinya sebesar 0,018 dimana nilai signifikansi tersebut $<\alpha(0,05)$, sehingga persepsi manfaat memiliki pengaruh yang positif dan signifikan terhadap minat beli.

5. Hasil analisis menunjukkan adanya pengaruh positif dan signifikan dari variabel kepercayaan terhadap minat beli. Hasil pengujian kedua variabel tersebut menunjukkan bahwa koefisien regresi dari pengaruh kepercayaan terhadap minat beli adalah sebesar 0,324 dan bernilai positif. Tingkat signifikansinya sebesar 0,000 dimana nilai signifikansi tersebut $<\alpha(0,05)$, sehingga kepercayaan memiliki pengaruh yang positif dan signifikan terhadap minat beli.

\section{Kesimpulan Masalah Penelitian}

Kesimpulan masalah digunakan untuk menjawab rumusan masalah yanng diajukan dalam penelitian ini yaitu apa pengaruh dari persepsi kemudahan penggunaan dan persepsi 
manfaat terhadap kepercayaan serta dampaknya terhadap minat beli.

Hasil penelitian membuktikan bahwa persepsi kemudahan penggunaan memiliki pengaruh paling besar tehadap kepercayaan dengan indikatornya adalah kemudahan mempelajari website, kemudahan mencari produk yang sesuai dengan kebutuhan, dan kemudahan menggunakan website dengan terampil dan tanpa kesulitan. Sedangkan persepsi manfaat memiliki pengaruh kedua dengan indikatornya adalah penggunaan website dapat meningkatkan performansi belanja, penggunaan website dapat meningkatkan produktivitas berbelanja, dan penggunaan website dapat meningkatkan efektivitas berbelanja. Dari hasil hasil penelitian juga diketahui bahwa kepercayaan berpengaruh terhadap minat beli dengan indikatornya adalah website dapat dipercaya, website dikenal sebagai situs yang dapat memenuhi janjinya, dan tidak ada alasan untuk khawatir saat menggunakan website.

\section{Keterbatasan}

Dalam penelitian ini terntunya masih ada keterbatasan-keterbatasan yang timbul. Keterbatasan yang di alami oleh peneliti adalah sebagai berikut: Jumlah responden hanya 150 , sehingga data yang diperoleh belum menggambarkan kondisi yang menimbulkan minat beli konsumen online secara luas. Selain itu, hanya dua variabel independen yang digunakan dalam penelitian ini yaitu persepsi kemudahan penggunaan dan persepsi manfaat, sehingga hasil yang didapatkan kurang maksimal. Juga teknik pengumpulan data yang dilakukan dalam penelitian ini hanya dilakukan dengan pengisian kuesioner dan tidak menggunakan teknik wawancara mendalam sehingga data yang diperoleh hanya berupa jawaban dari opsi yang telah dibuat.

Atas dasar keterbatasan tersebut, maka untuk penelitian yang akan datang diharapkan memberikan penjelasan lebih sebelum memberikan kuesioner, menggunakan jumlah sampel yang lebih banyak dan menambah jumlah variabel dalam penelitian. Agar mendapatkan hasil yang lebih bervariatif lagi dan hasilnya dapat menjadi implikasi manajerial baru bagi toko online berrybenka.com.

\section{REFERENSI}

Asosiasi Penyelenggara Internet Indonesia. 2014. "Profil Pengguna Internet Indonesia". Pusat Kajian Komunikasi Universitas Indonesia.

Bart, Yakov, Venkatesh Shankar, et al. 2005. "Are The Drivers and Role of Online

Trust the Same for All Web Sites and Consumers? A Large-Scale Exploratory Empirical Study". Journal of Marketing, Vol. 69, p. 133-152.

Davis, F.D. 1989. "Perceived Usefulness, Perceived Ease of Use, and User Acceptance of Information Technology". MIS Quarterly, Vol.13, No.3, p. 319-340.

Dharmmesta, Basu Swastha, dan T. Hani Handoko. 1997. Manajemen Pemasaran: Analisis Perilaku Konsumen. Yogyakarta: BPFE.

Engel, James F., Roger D. Blackwell, dan Paul W. Miniard. 2000. Perilaku Konsumen. Terjemahan. F.X. Budianto. Jakarta : Binarupa Aksara.

Ferdinand, Augusty. 2006. "Metode Penelitian Manajemen: Pedoman Penelitian untuk Penulisan Skripsi, Tesis, dan Disertasi Ilmu Manajemen". Semarang: Badan Penerbit Universitas Diponegoro.

Geffen, David, Elena Karahanna, dan Detmar W. Straub. 2003. "Trust and TAM in online shopping: An Integrated Model”. MISQ, Vol. 27, No. 1, p. 51-90.

Ghazizadeh, Mahtab, Yiyun Peng, et al. 2012. "Augmenting the Technology Acceptance Model with Trust: Commercial Drivers' Attitudes towards Monitoring and Feedback". Human Factors and Ergonomics Society. 
Ghozali, Imam. 2011. Aplikasi Analisis Multivariate dengan Program IBM SPSS 19. Semarang: Universitas Diponegoro.

Haryosasongko, Fajar Arie. 2015. "Pengaruh Persepsi Risiko, Persepsi Kemudahan, Dan Persepsi Manfaat Terhadap Minat Pembelian Online Pada Website Lazada.co.id di Kota Malang".

Heijden, Hans van der, Tibert Verhagen, dan Marcel Creemers. 2003. "Understanding Online Purchase Intentions: Contributions From Technology and Trust Perspective." European Journal of Information Systems, Vol. 12, p. 41-48.

Hoffman, D.L. dan T.P. Novak. 1996. "Marketing in Hypermedia Computer-Mediated Environments: Conceptual Foundations". Journal of Marketing, Vol. 60, p. 5068.

Jarvenpaa, S.L. dan N. Tractinsky. et al. 2000. "Consumer Trust In An Internet Store”. Information Technology and Management, Vol.1, No.1, p. 45-71.

Keller, Kevin L. 1998. Strategic Brand Management: Building, Measuring, and Managing Brand Equity. New Jersey: Prentice Hall.

Kim, J.H., M. Kim dan J. Kandampully. 2007. "The Impact of Buying Environment Characteristics of Retail Web Sites". Service Industries Journal, Vol. 27 No. 7, p. 865-80.

Kim, D.J., D.L. Ferrin, dan H.R. Rao. 2008. "A trust-based consumer decision-making model in electronic commerce: The role of trust, perceived risk, and their antecedents". Decision Support Systems, Vol. 44, No. 2, p. 544-564.

Kinnear, Thomas C. and James R. Taylor, 1995. Marketing Research: An Applied Approach. McGraw Hill Text.

Kotler, Philip dan Kevin Keller. 2009. Manajemen Pemasaran Jilid 1. Jakarta: Erlangga.

Koufaris, Mario dan Hampton-Sosa, William. 2004. "The Development of Trust In An Online Company by New Customers". Information and Management Journal, Vol. 41, p. 377-397.

Lee, C. dan G. Wan. 2010. "Including subjective norm and technology trust in the Technology Acceptance Model: a case of e-ticketing in China". ACM SIGMIS Database, Vol 41, No.4 , p. 40-51.

Lukman, Enricko. 2013. "Laporan: inilah yang dilakukan 74,6 juta pengguna internet Indonesia ketika online". https://id.techinasia.com/tingkah-laku-penggunainternet-indonesia. (Diakses pada tanggal 2 Desember 2015).

Marzuki. 2005. Metodologi Riset. Yogyakarta: Ekonisia.

MaxMonroe. 2015. "Trust, Kunci Utama Kesuksesan Bisnis E-Commerce". https://www.maxmanroe.com/trust-kunci-utama-kesuksesan-bisnis-ecommerce.html (Diakses pada tanggal 1 Januari 2016).

McGee, L.W. dan R.L. Spiro. 1991. "Salesperson and product country-of-origin effects on attitudes and intentions to purchase". Journal of Business Research, Vol. 22, p. 21-32.

McKinsey. 2013. "The Evolving Indonesian Consumer". Asia Consumer Insights Center.

Menkominfo. 2016. https://kominfo.go.id/content/detail/6983/menkominfo-perkirakantransaksi-e-commerce-capai-25-miliar-dollar/0/sorotan_media. (Diakses pada tanggal 3 Maret 2016).

Novak, Thomas P., Donna L. Hoffman, dan Yiu-Fai Yung. 2000. "Measuring the Customer Experience in Online Environments: A Structural Modeling Approach”. Marketing Science, Vol.1, No. 19, p. 22-42. 
Nurrahmanto, Prasetyo Agus. 2015. "Pengaruh Kemudahan Penggunaan, Kenikmatan Berbelanja, Pengalaman Berbelanja dan Kepercayaan Konsumen Terhadap Minat Beli Konsumen di Situs Beli Online Bukalapak.com." Skripsi Program Sarjana (S1) pada FEB Universitas Diponegoro Semarang: tidak diterbitkan.

Purbo, Onno W. dan Aang Arif Wahyudi. 2001. Mengenal E-Commerce. Jakarta: PT. Elex Media Komputindo.

Ramayah, T. dan Joshua Ignatius. 2005. "Impact of Perceived Usefulness, Perceived Ease of Use and Perceived Enjoyment on Intention to Shop Online”. ICFAI Journal of Systems Management (IJSM), Vol. 3, No. 3, p.36-51.

Reardon, J. dan McCorckle, D.E. 2002. "A Consumer Model for Channel Switching Behavior". International Journal of Retail \& Distribution Management, Vol. 30, p. $179-185$.

Rousseau, Denise M., Sim Sitkin, et al. 1998. "Not So Different After All: A Crossdiscipline View of Trust". The Academy of Management Review, Vol. 23, No.3, p. 393-404.

Sekaran, Uma. 2006. Metodologi Penelitian untuk Bisnis. Jakarta: Salemba Empat.

Setiadi, Nugroho J. 2003. Perilaku Konsumen: Perspektif Kontemporer pada Motif, Tujuan, dan Keinginan Konsumen. Jakarta: Kencana Prenada Media Group.

Sugiyono. 2011. Metode Penelitian Kuantitatif, Kualitatif dan R\&D. Bandung: Alfabeta.

Tan, Y.H. dan Thoen, W. 2001. "Toward A Generic Model of Trust For Electronic Commerce". International Journal of Electric Markets, Vol.5, No.2, p. 61-74.

Yoon, Sung-Joon. 2002. "The Antecedents And Consequences of Trust In OnlinePurchase Decisions". Journal of Interactive Marketing, Vol. 16, No. 2, p. 47-63.

www.alexa.com 